\title{
Form and Dimensional Accuracy of Surfaces Generated by Longitudinal Turning
}

Umberto Prisco, Antonino Squillace, Fabio Scherillo, Fabrizio Coticelli, Antonello Astarita

Department of Chemical, Materials and Production Engineering, University of Napoli Federico II, Piazzale Tecchio 80, 80125 Napoli, Italy

The influence of the dynamic behaviour of the machine tool/workpiece system on the surface accuracy plays an important role in finish machining. In particular, the machine tool/workpiece dynamics determines the topography of the machined surface, which is crucial in determining the quality and performance of a mechanical part. A model to predict the dynamic effects of the cutting process in turning, as part of a machining simulation framework, is presented in this paper. Thermally, kinematically and dynamically induced errors can be easily implemented into the proposed model. Finally, several examples of the use of this model under different turning conditions are presented and compared to typical machined surfaces. The proposed model can effectively compute the roughness, form and dimensional accuracy of a turned surface.

Keywords: turning, accuracy of machine tool, tool vibrations, surface topography

\section{References}

[1] PRISCO, U. (2014). Size-dependent distributions of particle velocity and temperature at impact in the cold-gas dynamic-spray process. Journal of Materials Processing Technology, Vol. 216, pp. 302-314.

[2] PRISCO, U. (2014). Thermal conductivity of flat-pressed wood plastic composites at different temperatures and filler content. Science and Engineering of Composite Materials, Vol. 21, No. 2, pp. 197-204.

[3] CARRINO, L., CILIBERTO, S., GIORLEO, G., PRISCO, U. (2011). Effect of filler content and temperature on steady-state shear flow of wood/high density polyethylene composites. Polymer Composites, Vol. 32, No. 5, pp. 796-809.

[4] BITONDO, C., PRISCO, U., SQUILACE, A., BUONADONNA, P., DIONORO, G. (2011). Friction-stir welding of AA 2198 butt joints: Mechanical characterization of the process and of the welds through DOE analysis. International Journal of Advanced Manufacturing Technology, Vol. 53, No. 5-8, pp. 505-516.

[5] RESHETOV D.N., PORTMAN V.T. (1988). Accuracy of machine tools, ASME PRESS, New York.

[6] SERRONI, G., SQUILlACE, A., PRISCO, U., BITONDO, C., PRISCO, A. (2011). Aircraft panels stiffened by friction stir welded extruded parts: Mechanical characterization. Metallurgia Italiana, Vol. 103, No. 1, pp. 35-39.

[7] ASTARITA, A., PRISCO, U., SQUILLACE, A., VELOTTI, C., TRONCI, A. (2015). Mechanical characterization by DOE analysis of AA6156-T4 friction stir welded joints in as-welded and post-weld aged condition. Materialpruefung/Materials Testing, Vol. 57, No. 3, pp. 192-199.

[8] BITONDO, C., PRISCO, U., SQUIllace, A., GIORLEO, G., BUONADONNA, P., DIONORO, G., CAMPANILE, G. (2010). Friction stir welding of AA2198-T3 butt joints for aeronautical applications. International Journal of Material Forming, Vol. 3 (SUPPL. 1), pp. 1079-1082.

[9] SQUILLACE, A., PRISCO, U. (2009). Influence of filler material on micro- And macro-mechanical behaviour of laser-beam-welded T-joint for aerospace applications. Proceedings of the Institution of Mechanical Engineers, Part L: Journal of Materials: Design and Applications, Vol. 223, No. 3, pp. 103-115.

[10] VITIELLO, A., PRISCO, U. (2009). Evaluation of drilling parameters effects on machinability of PM materials using ANOVA. Powder Metallurgy, Vol. 52, No. 2, pp. 164-171.

[11] PRISCO, U., D'ONOFRIO, M.C. (2008). Three-dimensional CFD simulation of two-phase flow inside the abrasive water jet cutting head. International Journal of Computational Methods in Engineering Science and Mechanics, Vol. 9, No. 5, pp. 300-319.

[12] PRISCO, A., ACERRA, F., SQUILlACE, A., GIORLEO, G., PIROZZI, C., PRISCO, U., BELLUCCI, F. (2008). LBW of similar and dissimilar skin-stringer joints. Part I: Process optimization and mechanical characterization. Advanced Materials Research, Vol. 38, pp. 306-319.

[13] MEOLA, C., GIORLEO, G., PRISCO, U. (2003). Experimental evaluation of properties of cross-linked polyethylene. Materials and Manufacturing Processes, Vol. 18, no. 1, pp. 135-144. 
[14] PRISCO, U., SQUILLACE, A., ASTARITA, A., VELOTTI, C. (2013). Influence of welding parameters and postweld aging on tensile properties and fracture location of AA2139-T351 friction-stir-welded joints. Materials Research, Vol. 16, No. 5, pp. 1106-1112.

[15] VITIELLO, A., SQUILLACE, A., PRISCO, U. (2007). Characterization of NiTinol under torsional loads through a numerical implementation of the Boyd-Lagoudas constitutive model and comparison of the results with experimental data. Smart Materials and Structures, Vol. 16, No. 1, pp. 76-82.

[16] MEOLA, C., CARLOMAGNO, G.M., SQUILlACE, A., PRISCO, U., MORACE, R.E. (2005). Analysis of composites with infrared thermography, Macromolecular Symposia, Vol. 228, pp. 273-286.

[17] PRISCO, U., CAPRINO, G., GIORLEO, G. (2004). Influence of the flexibiliser content on the monotonic and fatigue behaviour of a polyester resin for composites. Composites Part A: Applied Science and Manufacturing, Vol. 35, No. 9, pp. 1081-1089.

[18] SQUILlACE, A., PRISCO, U., CILIBERTO, S., ASTARITA, A. (2012). Effect of welding parameters on morphology and mechanical properties of Ti-6Al-4V laser beam welded butt joints. Journal of Materials Processing Technology, Vol. 212, No. 2, pp. 427-436

[19] SERRONI, G., BITONDO, C., ASTARITA, A., SCALA, A., GLORIA, A., PRISCO, U., SQUILLACE, A., BELLUCCI, F. (2011). A comparison between mechanical and electrochemical tests on Ti6Al4V welded by LBW. AIP Conference Proceedings, Vol. 1353, pp.1391-1396.

[20] VELOTTI, C., ASTARITA, A., SQUILlACE, A., CILIBERTO, S., VILLANO, M.G., GIULIANI, M., PRISCO, U., MONTUORI, M., GIORLEO, G., BELLUCCI, F. (2013). On the critical technological issues of friction stir welding lap joints of dissimilar aluminum alloys. Surface and Interface Analysis, Vol. 45, No. 10, pp. 1643-1648.

[21] PRISCO, U., GIORLEO, G. (2002). Overview of current CAT systems. Integrated Computer-Aided Engineering, Vol. 9, No. 4, pp. 373-387.

[22] FIALA, Z., JAROS, A., SEDLAK, J., KOLAR, L, BLAZKOVA, V. (2015). Effect of Spindle Unit Extrusion on Stability of Machining Process. Manufacturing Technology, Vol. 15, No. 3, pp. 329-333.

[23] VASILKO, K., MURČINKOVÁ, Z. (2015). Question of optimal cutting speed for machining by conventional and coated cutting tools. Manufacturing Technology, Vol. 15, no. 3, pp. 483-490.

[24] KOCMAN, K. (2015). Application of magnetic correlation analysis on the choice and correction of cutting parameters for automated manufacturing systems. Manufacturing Technology, Vol. 11, No. 11, pp. 28-32.

[25] DUGIN, A., POPOV, A. (2013). Increasing the accuracy of the effect of processing materials and cutting tool wear on the ploughing force values. Manufacturing Technology, Vol. 13, No. 2, pp. 169-173.

[26] CAROU, D., ŘEHǑ̌, J., MONKA, P., VILČEK, I., HOUDKOVÁ, Š. (2015). Insights for the selection of the machining parameters in the turning of difficult-to-cut coatings. Manufacturing Technology, Vol. 15, No. 3, pp. 295-303. 